\title{
GETTING INTO LIFE \& LIVING OF LOW-INCOME FACTORY WORKERS
}

TRINA. N.A. ${ }^{1}$, MOULY. A.R. ${ }^{2} \&$ TASMIA. F. ${ }^{3}$

1,2 Rajshahi University of Engineering \& Technology, Rajshahi, Bangladesh

3Bangladesh University of Engineering and Technology, Dhaka, Bangladesh

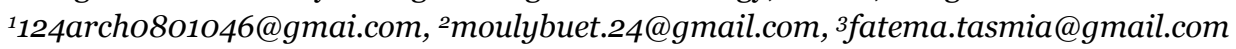

\begin{abstract}
Dhaka city is with its unplanned urban growth, creating shortage of land in comparison to the ever-increasing population, and uneven distribution of residential lands among different income groups. Moreover, factories are flourishing in Dhaka city, but no attempt has yet been made so far, to provide adequate to the workers with low-income either by the government or the factory owner. A housing unit demands the qualities of comfort, conveniences, and amenities; however, this demand requires considerable chunk of land and renters or owners need to have financial solvency to dwell in. Here come the premises on housing affordability. The paper aims at understanding the pulse of low-Income peoples 'housing' that include settlement pattern, house forms, space allocations, group accommodations, breathing spaces and sharing of facilities and utilities and consequently provide them a viable environment where life and living turn into a delight.
\end{abstract}

Keywords: Housing, affordability, settlement pattern, accommodations, low-income.

\section{Introduction}

Dhaka city is one of the most populous mega cities of the world. It has never been possible to meet the housing demand of the low-income Families of Dhaka city. The recent fixation of wage of garment workers starting from 5,300 puts them into one of the subgroups of Middle-Income Category: Lowmiddle Income of income bracket Tk 5000 to 10,000. However, considering inflation workers are to be considered within Low income Category of the above statistical table of income bracket tk.25005000.These people are 35\% of the total population of Dhaka city. Being one of the majorities they occupy only $20 \%$ of the cities residential land area. This large portion of the city's population mostly comprising of factory workers is living in informal sector housing such as slums, squatters, and messes under unhealthy living condition with low quality houses, inadequate physical amenities, and social services. Dhaka has some of the highest neighbourhood densities where some slum (shantytown) population densities reach up to 4,200 per acre and even more.

There are several parameters of the physical requirements of housing affordability namely land, price, infrastructure cost, building material and construction cost and space allocation that are responsible for increasing the housing unit price and thus the rent. The localities of Mirpur, Gazipur and Savar of greater Dhaka city (where a good number of factories exist) have buildable land and the prices are still comparatively lower. Affordability for this income group also calls for housing that are 'reasonably adequate in standard and location' does not cost so much that a household is unlikely to be able to meet other basic needs on a sustainable basis.

\section{Literature Review}

Population explosion and massive urbanization are two strong forces that is shaping our cities of present world. In developed countries almost 84 per cent people will live in cities by 2030 where the percentage of people in developing countries will be over 56 . The concerning issue is throughout this process a huge number of city dwellers are already living in below standard conditions. A sample of 116 cities shows that for Africa, Asia, Latin America and Oceania, a house or yard water connection exists in only 40 to 80 per cent of households, whereas levels of access to a sanitation infrastructure is far worse, at only 18 to 41 per cent (UNDESA, 2004). These numbers imply that the low-income people of our societies are living without proper facilities and most cases at unhealthy situations.

Studies in environmental psychology suggest the following four culturally determined basic spatial needs that are universal to human beings: 
- The need for privacy

- The need for personal space

- The need for easy access to social interactions

- The right to safe and defensible space

For design of domestic space and housing, the components of the cultural determinants are personal space, territoriality, privacy regulation and boundary controls. Privacy is a universal phenomenon-is manifested differently in different cultures. The common element is the control of unwanted interpersonal interactions and communication. The rules and symbols of privacy controls influence the flow of information and communication at individual, group, and social levels. But this is an utmost necessity even for people with lowest income range anywhere in the world.

Based on proxemics' or the study of people's use of space, Felipe and Sommer (1972) defines personal space. In a personal space invisible boundary are created in relation to each individual and the boundaries define a set of concentric zones of accepted behaviour. Also stress among persons is created if the zones are violated without warning. The design and use of domestic activities are organized by the cultural pre-disposition related to the meaning of binary oppositions. These binary oppositions include male and female, public and private, front and back, clean and dirty, symbolic and secular. It is also important that the ordering of domestic activities and spaces ought to conform to prescribed cultural conventions. Though it is seen that people manipulate the pre-defined spaces according to their needs and people with lower income range tends to compromise the basic demands of a comfortable living space.

Hence for designing a living space for low income working people with minimum facilities the idea of adequate shelter is considered. Adequate shelter means more than a roof over one's head. It also means adequate privacy; adequate space; physical accessibility; adequate security; security of tenure; structural stability and durability; adequate lighting, heating and ventilation; adequate basic infrastructure, such as water-supply, sanitation and wastes-management facilities; suitable environmental quality and health-related factors; and adequate and accessible location with regard to work and basic facilities; all of which should be available at an affordable cost. (Habitat Agenda and Istanbul Declaration UNCHS (1996,50). In our study Largely three types of income groups are found among nuclear families. The income of the workers is ranged from 5000 BDT to 15000 BDT. Depending on the income the economic classes are identified, and each class has its own set of dwelling pattern and social facilities according to their affordability.

\section{Objectives}

- In local context, extensive reconnaissance survey on the living pattern of factory workers as for example living condition on the whole, internal arrangement of housing unit, different types of relevant house forms or housing options available to workers, the settlement patterns and its incremental development.

- Analyse the information and data in terms of physical, social, and economic aspects. List the pertinent requirement of BNBC code and standards.

- Then arrive at a cut-off point regarding the spatial requirements, choices on building materials and construction techniques, provision of necessary facilities and utilities and open spaces set ups.

\section{Methodology}

In this study the total process has been conducted in two phases. 


\subsection{PHASE 01 - STUDY}

In the Kabirpur, Savar study area 06 factories are identified within 2-3 miles of the selected location of the slums, squatters, and messes in the ward map where the workers live. Similarly, in Ershadnagar that number was 09. Literature search and Field Study alongside sketches and photographs was conducted to collect the necessary data and information on

\subsubsection{Settlement features:}

Land-uses, Housing stock, Density, Infrastructure, Facilities and services, civic amenities, general layout, the morphological growth of the settlements.

\subsubsection{Physical aspects:}

The relevant house forms and housing options available to workers- internal layout and arrangement of units, organization of spaces, space hierarchy, allocated space per person within the built form, Open and built area ratio, Building material and construction techniques etc.

\subsubsection{Social Aspects:}

Privacy, Demographic facts, Gender issues, security, profile of dwellers.

\subsubsection{Economic Aspects:}

Income, Expenditure, Saving, Land value and rents paid.

\subsection{PHASE 02 - ANALYSIS AND RECOMMENDATIONS}

Analysis of information and data to formulate a program where conclusive statements on spatial requirements and allocations, choices on building materials and construction techniques, provision of definite facilities and utilities and open space system in accordance to standards and BNBC code.

\section{Living pattern of factory workers}

Most of the garment factories are situated in Savar, Narayanganj, Gazipur, Keraniganj and some areas like Mirpur, Badda in Dhaka. House rent in those areas is very high and because of low wage workers have to live in slum or slum like establishment for example shantytown. These places are very cramped and dilapidated and derived of most of the basic facilities. Numbers of toilets are also incongruous comparing to the numbers of inhabitants. Every morning dwellers have to stand in a long queue to go to toilet and get water for household works. The environment in which workers live is very asphyxiating and choking. So, garments factories are not paying these workers a minimum amount to have a liminal decent living place. Our study areas were Ershadnagar of Tongi and Kabirpur of Savar.

Most of the houses of Kabirpur are beneath standards. Landowner built those houses arbitrarily and improperly. The numbers of toilets are very inappropriate compared to numbers of inhabitants. There is lack of attached toilets and kitchen. Most of the families share only one kitchen. The toilet is a sanitary one but it is very scruffy and filthy, emanating rancid odour. In some situation there is family of 5-6 members live in a single room because they cannot afford the cost of two rooms. When any guest comes from their village it becomes very difficult for them to accommodate. Also, there is no privacy. 

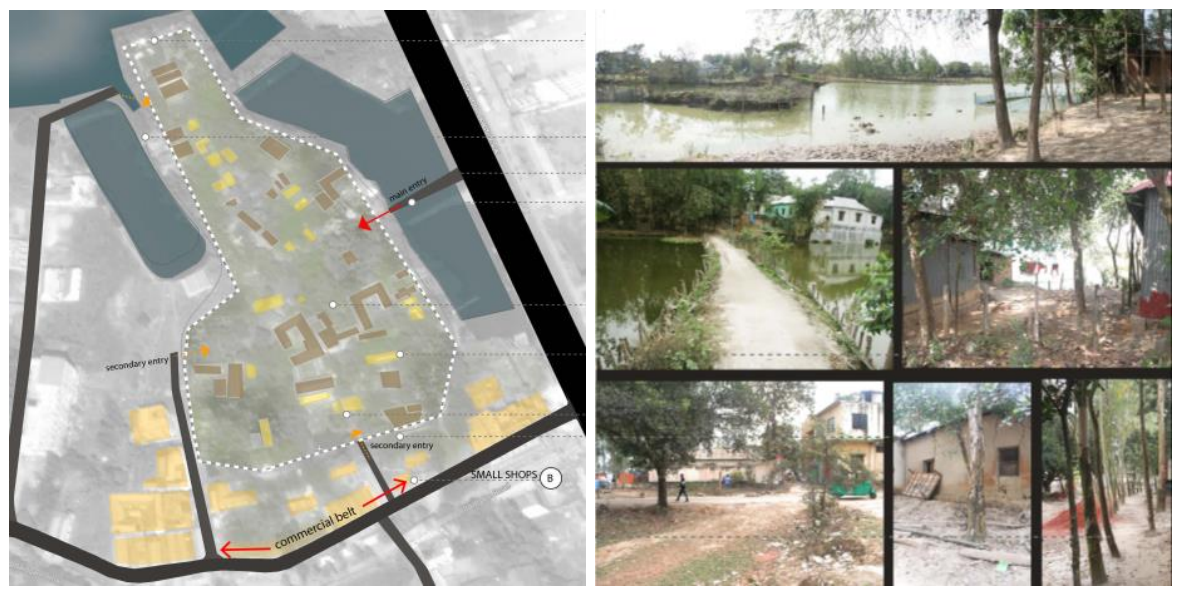

Figure 1, Site plan and surrounding existing condition of study area- Kabirpur, Savar

In Ershadnagar, the inhabitants do not pay any rent and do not need permission while extending their dwelling units for any economic activities. The types of home-based jobs and their working spaces in each individual family have different features. As the spaces are very congested, they have to find or create their own working spaces, within this limitation. Therefore, it is important for the bustee people to find the types of jobs, which are suitable in these dwelling units. Thus, flexibility of space is vital for the families who are involved in home-based production because the lack of space forces certain home-based work to choose spaces that are not suitable for such activities.
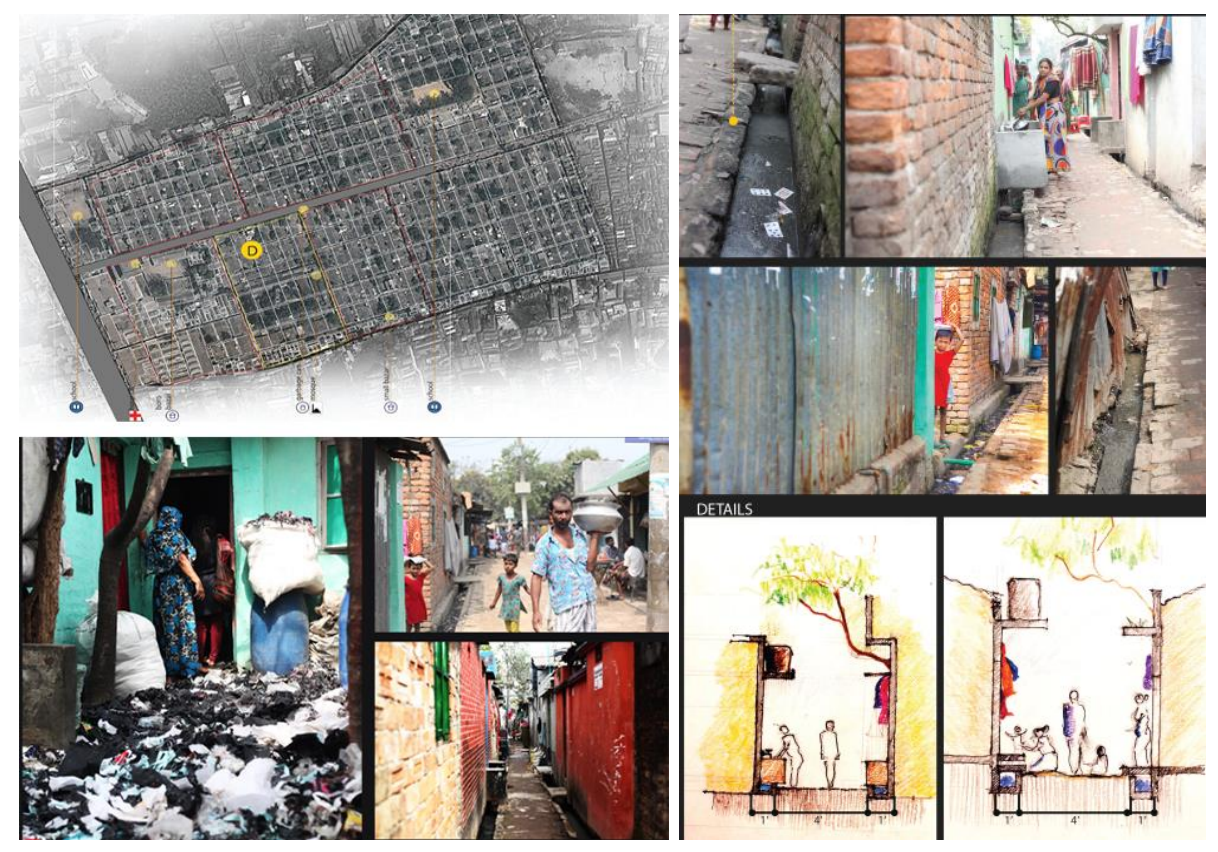

Figure 2, Site plan and surrounding existing condition of study area- Ershadnagar, Tongi, Gazipur

\section{Case studies}

While interviewing the workers were asked whether they can save money after paying their lively costs. They said that their intention before migrating to city life was to save some money then come back again to their roots. But they cannot save money for their future. In this paper we illustrate the living pattern of three factory worker according to their own explanation. 


\subsection{CASE STUDY 01}

A 17 years age old girl Swarna from Bikrampur. She came to Ershadnagar, Tongi, Gazipur, when she was 6 years old with her parents. Life has always been harsh to her. She started working as a garment worker when she was in primary school. Her current salary is 8000 takas. She says it is very hard to maintain her family with it. Their family income in total is 14000 takas. But the expenditure is 15000 taka / month. So, there is no savings. Her family has to share a toilet and a kitchen with another family of 07 members.

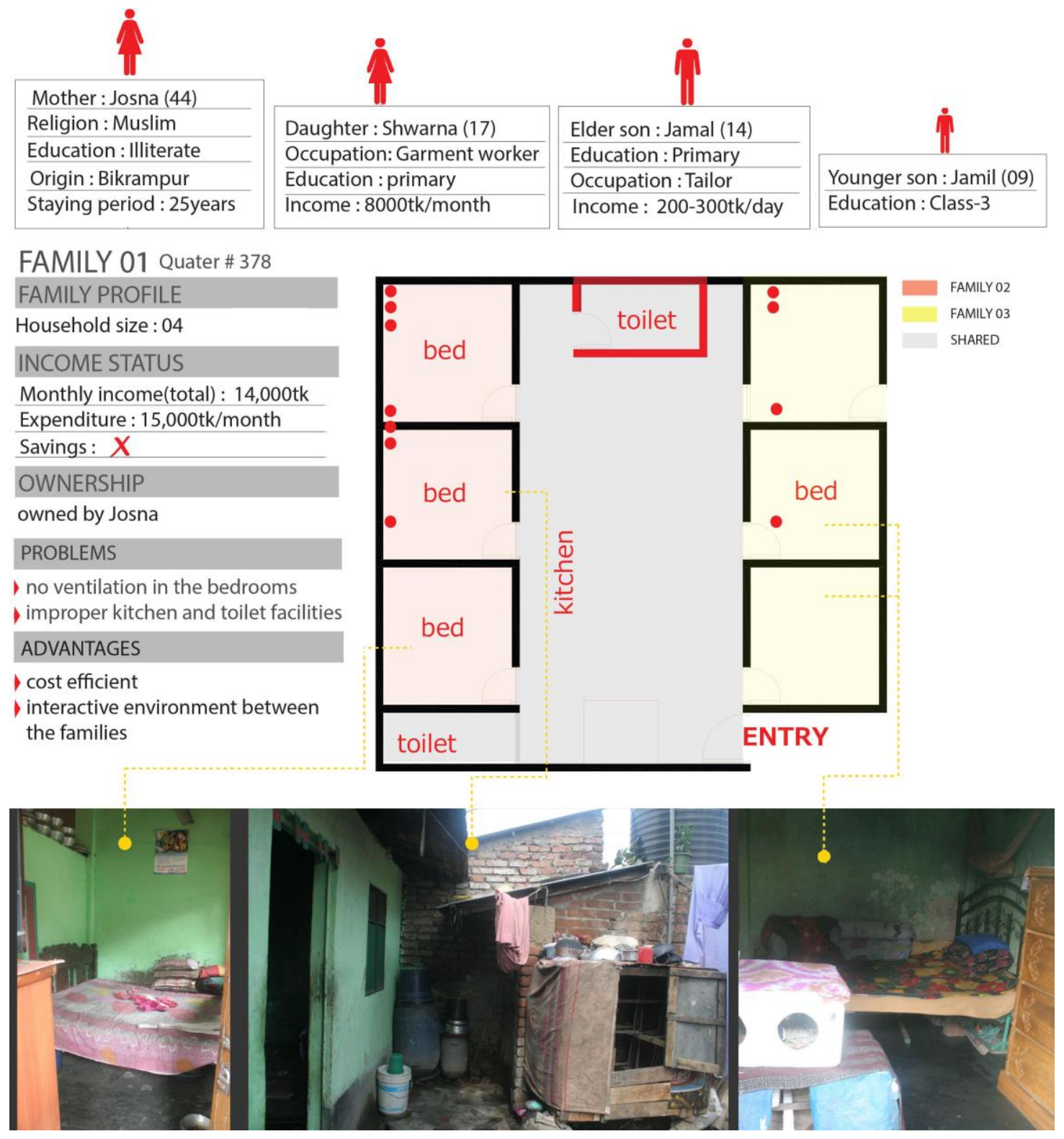

Figure 3, Illustrated Plan and existing condition of dwelling type of case study 01- Ershadnagar, Gazipur

\subsection{CASE STUDY 02}

Habibur Rahman (50) has been working in this factory for 18 years and his salary is now 6400 taka and including overtimes he gets almost 10000 in a month. He says that it is very difficult to maintain his family with this amount of money. Delay of payment is a common incident. But expenditure is much higher than income. The dwelling has only one toilet which is used by 17 members. The previous 
kitchen was converted to a bedroom and now shifted in open courtyard. The electricity bill is 10otk/month. They use clay stove for cooking and the drainage system is in extremely bad condition.

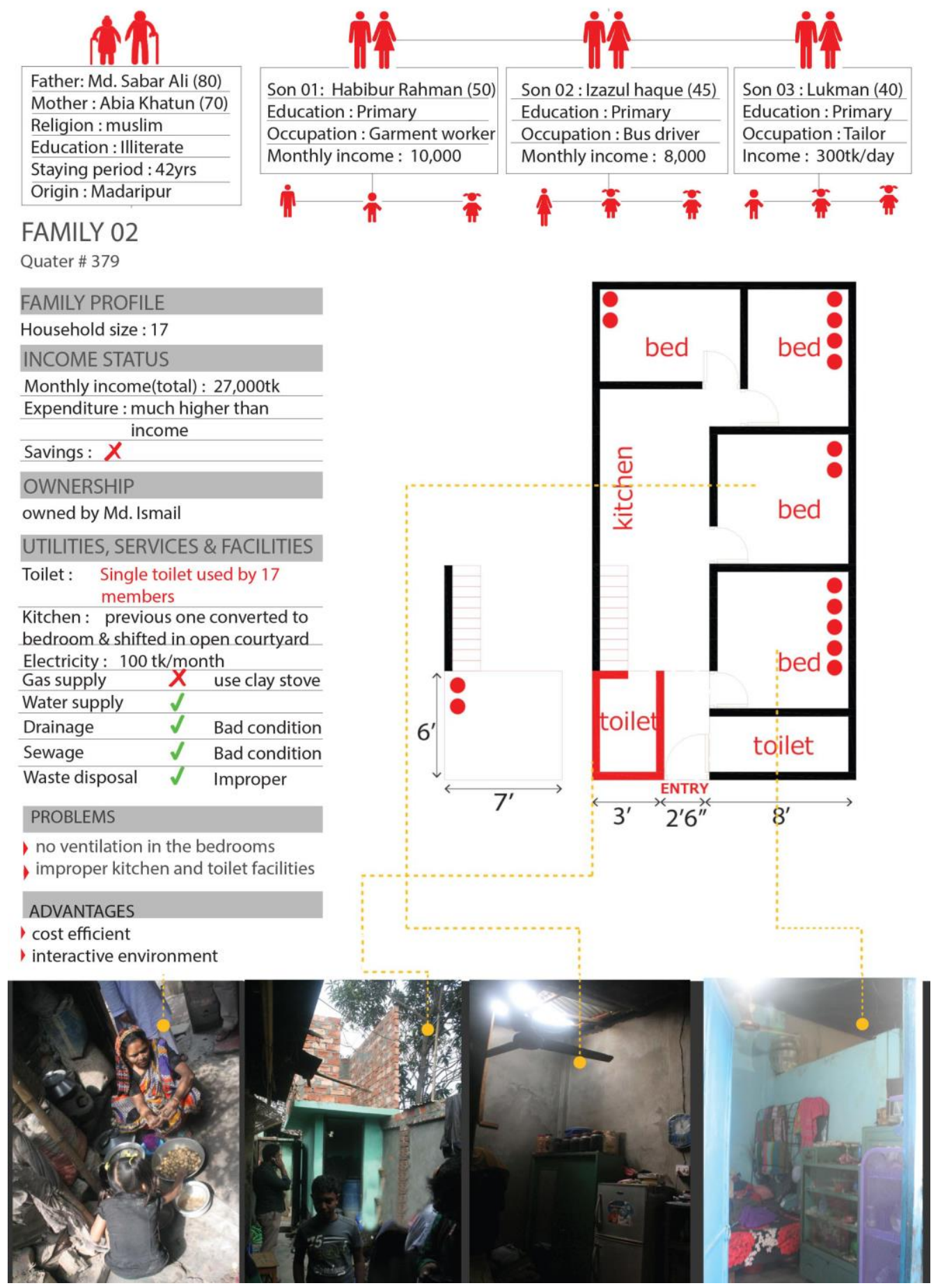

Figure 4, Illustrated Plan and existing condition of dwelling type of case study 02- Ershadnagar, Gazipur6.3.

\section{CASE STUDY 03}

Selina is another girl from Rangpur. She came Savar with her husband to alter the conditions of their life. Both Selina and her husband are garments workers in Polmal Pvt Ltd in Savar. At present they are living in Kabirpur, Savar. Her living place is a very congested space. There are separate toilets for 
male-female but shared. Everyday morning, she has to stand in a queue to get water and then in another queue for having access to toilet. Her present salary is 6400 taka and she is an operator.

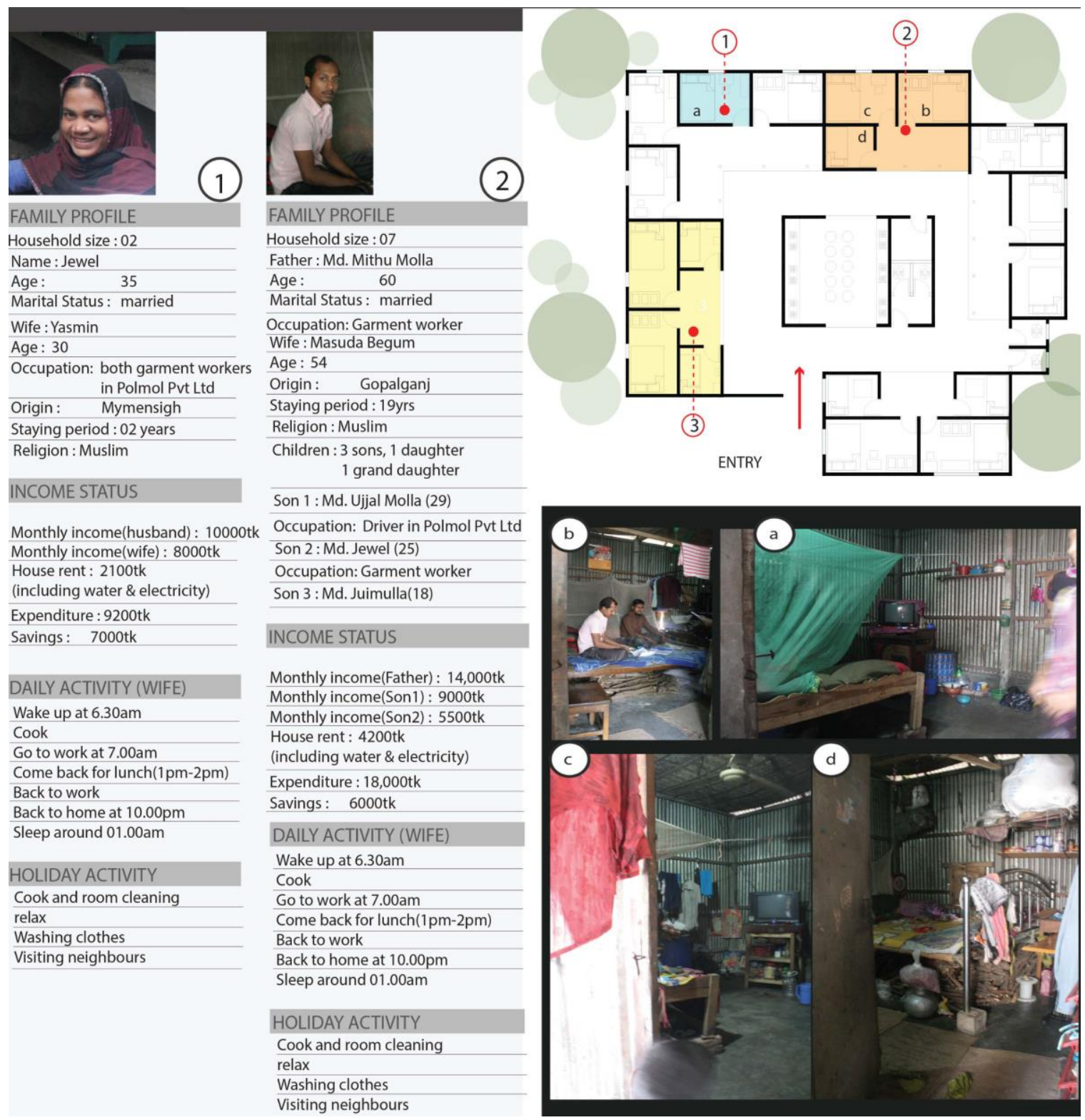

Figure 5, Illustrated Plan and existing condition of dwelling type of case study 03- Kabirpur, Savar

\section{Findings}

The study has brought about some comparison of facilities that represents different economic condition of workers. Although according to the rent the facilities in their dwelling pattern are not justified in these case studies. Whenever the income level increases, it is required that the affordability for house rent increases. When the rent increases, the facilities in their dwelling pattern needed to be get better than the people with lower income. This differentiation is absent in many aspects like the space for residing, the building materials of building construction, the necessary service facilities, privacy concerns, exposure to open spaces etc. 


\section{According to BNBC:}

Habitable rooms:

\begin{tabular}{|l|l|}
\hline $\begin{array}{l}\text { One roomed dwelling unit } \\
\text { shall have a multi-purpose } \\
\text { room which may include an } \\
\text { alcove or space for cooking }\end{array}$ & $\begin{array}{l}\text { The min area of the room } 12 \mathrm{sqm} / 129.2 \mathrm{sq} . \\
\mathrm{ft} \text { with a min width of } 2.5 \mathrm{~m} / 8.2 \mathrm{ft}\end{array}$ \\
\hline Two roomed dwelling units & $\begin{array}{l}\text { The min size of any room } 6 \mathrm{sqm} / 64.6 \mathrm{sq} . \mathrm{ft} \\
\text { with a min width of } 2.1 \mathrm{~m} / 7 \mathrm{ft} . \text { The min total } \\
\text { area of two rooms } 15 \mathrm{sqm} / 161.5 \mathrm{sq} . \mathrm{ft}\end{array}$ \\
\hline
\end{tabular}

All habitable rooms shall have a clear height of $2.75 \mathrm{~m} / 9 \mathrm{ft}$

For sloped roof, the min average height $2.75 \mathrm{~m}$ with a min $2 \mathrm{~m}$ at lowest side

Kitchen:

\begin{tabular}{|l|l|l|}
\hline One roomed house & $\begin{array}{l}\text { Cooking space provided } \\
\text { in multi-purpose room }\end{array}$ & $\begin{array}{l}\text { Min area 2.25sqm/24.2 sq. } \\
\mathrm{ft} \& \text { min width 1.2m/4ft }\end{array}$ \\
\hline Two roomed houses & Separate kitchen & $\begin{array}{l}\text { Min area } 3.25 \mathrm{sqm} / 35 \mathrm{sq} . \mathrm{ft} \\
\text { \& min width } 5.2 \mathrm{ft}\end{array}$ \\
\hline
\end{tabular}

Min clear height of the kitchen or cooking space shall be $7 \mathrm{ft}$ or $2.15 \mathrm{~m}$

Bathroom and water closet:

\begin{tabular}{|l|l|}
\hline Independent water closet & $\begin{array}{l}\text { Min width } 0.9 \mathrm{~m} / 3 \mathrm{ft} \text {, length } 1.15 \mathrm{~m} / 3.8 \mathrm{ft} . \text { The } \\
\text { water closet shall be fitted with a door }\end{array}$ \\
\hline $\begin{array}{l}\text { Independent bathroom } \\
\text { without water closet }\end{array}$ & Min width $1 \mathrm{~m} / 3.3 \mathrm{ft}$, min length $1.4 \mathrm{~m} / 4.6 \mathrm{ft}$ \\
\hline $\begin{array}{l}\text { Combined bathroom and } \\
\text { water closet }\end{array}$ & $\begin{array}{l}\text { Min size } 1.8 \mathrm{~m} 2 / 19.4 \mathrm{sq} . \mathrm{ft} \text { with a min width of } \\
1 \mathrm{~m} / 3.3 \mathrm{ft} .\end{array}$ \\
\hline
\end{tabular}

The min clear height of bathrooms and water closet shall be $2.15 \mathrm{~m} / 7 \mathrm{ft}$

Balcony and corridor:

Individual balcony with a unit Balcony $\quad$ Min width $0.9 \mathrm{~m} / 3 \mathrm{ft}$

\begin{tabular}{l|l} 
serving more than one dwelling units & Min width $1.2 \mathrm{~m} / 4 \mathrm{ft}$
\end{tabular}

Light and ventilation:

Every room, bathroom and kitchen shall have windows in an external wall opening on a courtyard, a balcony not wider than $2.5 \mathrm{~m}$ or the exterior. The aggregate area of openings in the exterior wall of a habitable room or kitchen shall not be less than $12 \%$ of the floor area and that for a non- habitable room such as bath room, water closet or stair shall be at least $8 \%$ of the floor area.

\section{Dwelling types according to $\mathrm{BNBC}$ and Income range:}
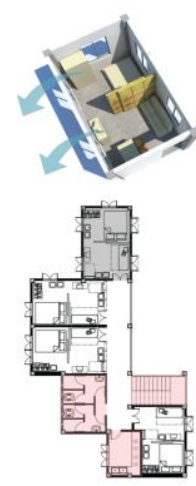

Household Size: 1-2 Unit Size: 200 sft
Shared services
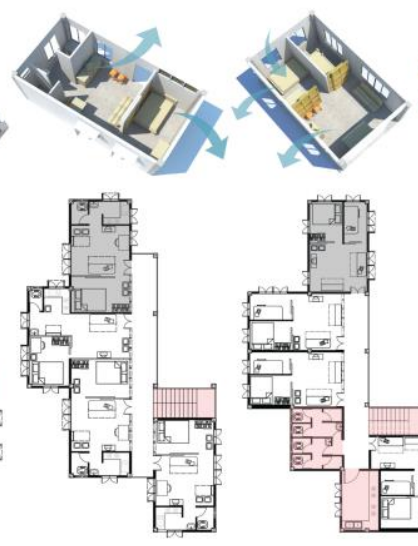

Household Size: $3-4$ Unit Size: 260 sft

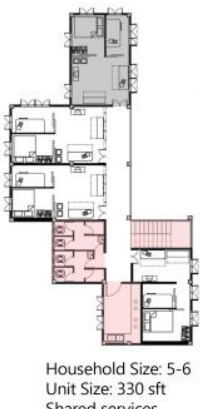

Unit Size: 330 sft
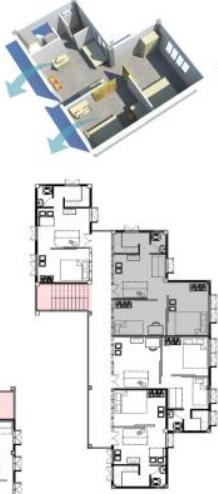

Household Size: 5-6 Unit Size: 450 stt
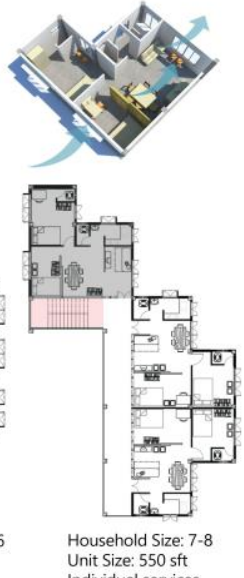

Unit Size: 550 stt

Figure 6, Illustrated proposed Plan for different dwelling type according to BNBC and income group 


\begin{tabular}{|c|c|c|c|c|c|}
\hline Type & $\begin{array}{c}\text { House } \\
\text { hold } \\
\text { Size }\end{array}$ & Income & $\begin{array}{c}\text { Affordibi } \\
\text { lity } \\
(30 \%)\end{array}$ & $\begin{array}{c}\text { Unit Size (Sq. } \\
\text { Ft.) }\end{array}$ & Design \\
\hline 01 & $1-2$ & $5000-$ & $\begin{array}{c}1500- \\
13000\end{array}$ & $\begin{array}{c}120+\text { shared } \\
80=200\end{array}$ & $\begin{array}{c}\text { 1 bedroom, 1 living \& dining, shared } \\
\text { services }\end{array}$ \\
\hline 02 & $3-4$ & $5000-$ & $1500-$ & $200+60$ & 1 bedroom, 1 living \& \\
& & 8500 & 3960 & $=260$ & dining, services \\
\hline 03 & $5-6$ & $5000-$ & $1500-$ & $250+$ shared & 2 bedrooms, 1 living\& dining, \\
& & 8500 & 2550 & $80=330$ & shared services \\
\hline 04 & $5-6$ & $9000-$ & $2700-$ & $350+80$ & 2 bedrooms, 1 living \& dining, \\
& & 13000 & 3960 & $=450$ & services \\
\hline 05 & $7-8$ & $9000-$ & $2700-$ & $450+100=$ & 2 bedrooms, 1 living \& dining, \\
& & 13000 & 3960 & 550 & services \\
\hline
\end{tabular}

\section{Conclusion}

The study on the income status and the living patterns of the factory worker of the Ershadnagar, Tangi, Gazipur and Kabirpur of Savar will reveal the functional needs and existing condition in settlements of different types of workers. The living patterns found in the survey are organically development by the workers for satisfying the needs of various income groups. Worker of a certain income group cannot afford to have other housing types those are associated with higher income groups of workers. Moreover, the higher income worker group may need comparatively better housing environment and facilities. The scope of this study is to pave the way for the housing research initiative to develop more sustainable housing systems utilizing limited resources to satisfy housing needs for workers. In this regard the study can be assessed for future development or future planning of housing solutions for garments workers that can satisfy the diverse functions as required by various income groups.

\section{Acknowledgement}

The authors express their earnest gratitude to the to the Department of Architecture of the Bangladesh University of Engineering and Technology, Dhaka, Bangladesh where the data collection and rigorous survey was arranged. Authors also acknowledges the contributions of the Studio project: Level 4 Term 2

Studio Teachers: Prof. Khaleda Ekram, Prof. Shahidul Ameen, Catherine D. Gomes, Fatema Meher Khan, Samia Sharmin and Tahajibul Hossain.

Group Members: Fatema Tasmia, Nazia Afrin Trina, Mehnaz Tabassum and Ahsan Sumit; Department of Architecture, Bangladesh University of Engineering and Technology, Dhaka, Bangladesh.

\section{References}

Sikdar, M. M. H., Sarkar, M. S. K., \& Sadeka, S. (2014). Socio-economic conditions of the female garment workers in the capital city of Bangladesh. International Journal of Humanities and Social Science, 4(3), 173-179.

Islam, N., \& Bari Chowdhuri, A. S. (2012). Socio-economic factors of readymade garments workers in Bangladesh. DU Journal of Marketing(15).

Evolving Urban Form: Dhaka ‘newgeography’ February 05,2014, Last Updated: 02/05/2014

The National Affordable Housing Consortium (NAHC), Australia. 